\title{
Organic cultivation of yellow passion fruit using tall seedlings with long root systems
}

\author{
Nilciléia Mendes Silva ${ }^{1 *(1)}$, Sebastião Elviro Araújo Neto' (1D), \\ Luís Gustavo de Souza e Souza', Thays Lemos Uchôa', Regina Lúcia Félix Ferreira' \\ 'Federal University of Acre, Rio Branco, Brazil \\ *Corresponding author, e-mail: nilcileia-ac@hotmail.com
}

\begin{abstract}
Studies related to adaptation to the environment and different conditions of water availability contribute to decision-making regarding the management of any crop to be implanted. Accordingly, this work aimed to evaluate the yield and quality of organic yellow passion fruit cultivated in a long root system in dryland conditions. The experimental design was in randomized blocks, with five treatments and four replications with four plants each. The treatments consisted of the alteration of the length of the root system, namely: $\mathrm{Tl}=25 \mathrm{~cm}$; $\mathrm{T} 2=50 \mathrm{~cm} ; \mathrm{T} 3=75 \mathrm{~cm} ; \mathrm{T} 4=100 \mathrm{~cm}$; and $\mathrm{T} 5=125 \mathrm{~cm}$. At 120 days after emergence (DAE), the seedlings were transplanted to the field and the following variables were evaluated: plant height $(\mathrm{cm})$ and base diameter $(\mathrm{mm})$ at 120 DAE; total titratable acidity (TTA), total soluble solids (TSS), Ratio (TSS/TTA); and fruit yield. The cultivation of tall seedlings with a long root system provides the maintenance of production during the dry season. The TTA, TSS, and the ratio do not change when modifying the length of the root system, although they do change with the harvest season. The cultivation of passion fruit in an organic system using plants with a long root system with an estimated length of $114 \mathrm{~cm}$ provides a higher fruit yield $\left(7,472 \mathrm{~kg} \mathrm{ha}^{-1}\right)$ in 22 months of cultivation.
\end{abstract}

Keywords: fruticulture, organic agriculture, Passiflora edulis Sims, plant growth

\section{Introduction}

The edaphoclimatic conditions of the state of Acre allow the cultivation of tropical fruits, such as the passion fruit, for providing a longer production period as a consequence of the non-shutdown in production given the absence of cold $\left(<16^{\circ} \mathrm{C}\right.$ ) in the region (Uchôa et al., 2018). In spite of the low yield in the state $(8.27 \dagger$ $\left.\mathrm{ha}^{-1}\right)$ (IBGE, 2016), passion fruit presents great social and economic importance since its cultivation is primarily performed by family farmers, who find in this crop a technically and economically viable option for offering a quick economic return and a well-distributed income in most months of the year (Araújo Neto et al., 2008; Meletti, 2011).

In an organic system, the yield varies from 5.03 to $21.6 \mathrm{tha}^{-1}$, with a mean total cost from $R \$ 0.64 \mathrm{~kg}$ to $R \$ 1.38 \mathrm{~kg}$, being necessary to increase the yield in order to reduce costs and maximize profit (Araújo Neto et al., 2008; Araújo Neto et al., 2014).

One of the low yield issues is water deficit, which increases the growth rate of the leaves, reducing from 50 to $75 \%$ of the vegetative growth and, paralyzes the production of flowers, reducing the fruit mass and the amount of pulp produced (Souza et al., 2018; Uchôa et al., 2018). In spite of the high level of annual rainfall in the state, its distribution is uneven (INMET, 2017). In the drought period, there is a shortage of water and low productivity (Araújo Neto et al., 2009; Rezende et al., 2017; Uchôa et al., 2018).

In this perspective, the production of seedlings with a long root system can be implemented as a new planting technology, since there will be greater resistance in field to prolonged drought periods, with the exploration of a greater volume of soil and water, besides the greater vegetative biomass of the seedling (Silva et al., 2018). Allied to the low cost of the organic cultivation of passion fruit (Araújo Neto et al., 2008), the prolongation of the harvest can increase the profitability of the activity and the offer of the fruit in periods of higher prices (off-season).

Therefore, this work aimed to evaluate the yield and quality of the organic yellow passion fruit of long root system in conditions of dryland cultivation.

\section{Material and Methods}

The experiment was conducted in the period from November 2015 to August 2017, in the Seridó 
Ecological Site, Rio Branco, state of Acre, located in the coordinates $9^{\circ} 53^{\prime} 16^{\prime \prime}$ S and $67^{\circ} 49^{\prime} 11^{\prime \prime}$ 'W, with elevation of $170 \mathrm{~m}$. The soil of the experimental area is classified as an alitic-plinthosolic YELLOW ARGISOL. The climate of the region is hot and humid, of the Am type, according to the classification by Köppen (Alvares et al., 2014), with mean annual temperatures around $24.5^{\circ} \mathrm{C}$, air relative humidity of $84 \%$, and annual rainfall ranging from 1,700 $\mathrm{mm}$ to $2,400 \mathrm{~mm}$.

The experimental design was in randomized blocks, with five treatments and four replications, containing four plants each. The treatments were constituted by alterations in the length of the root system, namely: $\mathrm{T}_{1}=0.25 \mathrm{~m}, \mathrm{~T}_{2}=0.50 \mathrm{~m}, \mathrm{~T}_{3}=0.75 \mathrm{~m}, \mathrm{~T}_{4}=1.00 \mathrm{~m}$, and $T_{5}=1.25 \mathrm{~m}$. To achieve this length, the seedlings were produced in tubes of polyvinyl chloride (PVC) with a 75 $\mathrm{mm}$ diameter according to their respective treatments.

For the formation of the seedlings of yellow passion fruit, the PVC tubes were filled with a substrate with the following composition: $33 \%$ of sand, $33 \%$ of an organic compound, $33 \%$ of a stem conditioner of ouricury palm, $1.0 \mathrm{~kg} \mathrm{~m}^{-3}$ of dolomitic limestone, $1.5 \mathrm{~kg} \mathrm{~m}^{-3}$ of natural thermophosphate, and $1.0 \mathrm{~kg} \mathrm{~m}^{-3}$ of potassium sulfate, in the period from July to November 2015. A synthetic variety of an F2 generation of yellow passion fruit was used in this experiment, originated from the Germplasm Bank of the Federal University of Acre, progenies 2, 20, 22, 23, 33, 35, and 37 (Negreiros et al., 2008).

To facilitate the removal of the root system during transplantation, a longitudinal cut was performed in the PVC tubes, which were later sealed with adhesive tape to allow the filling with the substrate. The seedlings were produced in a plant nursery covered with a transparent wrap of $100 \mu$, remaining in it for 90 days, with irrigation being performed twice a day, maintaining the substrate within field capacity.

The preparation of the area was performed by mowing the spontaneous vegetation with the aid of a motorized backpack brush cutter, and after the natural drying of the straw, the passion fruit seedlings were transplanted to the groves corresponding to the length of the root system.

The cultivation of the yellow passion fruit was conducted in a vertical trellis system with smooth wire $n^{\circ}$ 12 at a $2 \mathrm{~m}$ height. The plants were conducted in a $4 \mathrm{~m}$ spacing between rows and $3 \mathrm{~m}$ between plants $(833.33$ plants $\mathrm{ha}^{-1}$ ). The planting groves were fertilized with 500 $\mathrm{g}$ of limestone and $200 \mathrm{~g}$ of Yoorin ${ }^{\circledast}$ (thermophosphate).

Plague control was performed according to the legislation on organic vegetal production, with preventive applications of a microbial insecticidal based on Bacillus thuringiensis, specifically for leaf-feeding Caterpillars (Dione juno juno and Agraulis vanilae vanilae), and neem oil at $1 \%$. For the control of curculionids (Philonis passiflorae), a mixture of $1 \%$ neem oil $+4 \%$ of a sulfurbased broth was inserted in the stem hole with the aid of syringes, followed by recovery grafting in plants with severe damage levels, according to the methodology proposed by Rezende et al. (2017).

Periodic mowing interventions were performed along with the crowning of the plants every 60 days for the control of spontaneous weeds. The harvests were performed twice a week, collecting fallen fruits on the ground and those with $50 \%$ of husk coloration.

The plant height $(\mathrm{cm})$ and the base diameter $(\mathrm{mm})$ were evaluated at 120 days with the aid of a measuring tape and a digital pachymeter with a precision of 0.01 $\mathrm{mm}$, respectively. The chemical quality evaluation of the fruits was performed in samples with ten mature fruits per plot. The value of total soluble solids (TSS) was measured using a digital refractometer with automatic temperature control, with the results expressed in Brix (AOAC, 2012); for the total titratable acidity (TTA), $1 \mathrm{~mL}$ of passion fruit juice diluted in $50 \mathrm{~mL}$ of distilled water was titrated with sodium hydroxide $(\mathrm{NaOH})$ at $0.1 \mathrm{~N}$, using $1 \%$ phenolphthalein as an indicator, with the results expressed in percentage of citric acid (AOAC, 2012); the ratio value was determined by the ratio between the TSS and the TTA.

The mean number of fruits per plant was obtained by the quotient of the total number of fruits divided by the number of plants in each experimental unit. The mean fruit mass was estimated by the quotient of the total fruit mass by the number of fruits harvested in each plot ( $g$ fruit $\left.^{-1}\right)$.

The yield was estimated by the product of the mean fruit mass, the number of fruits per plant, and the final plant stand in harvests 1 (from April to August 2016) and 2 (from October 2016 to August 2017) expressed in $\mathrm{kg} \mathrm{ha}^{-1}$. For the total yield, the yield of both harvests was considered.

Before the statistical analysis, the presence of outlier data was verified. The normality of errors was analyzed by the Shapiro-Wilk test, and the homogeneity of variances was analyzed by the Bartlett test. After verifying these assumptions, the data were subjected to the $\mathrm{F}$ test. For the fruit quality variables, a joint analysis was performed between seasons and length of the root system, applying a regression test for the means of the quantitative factor, and Tukey's test for the means of the qualitative factor. 


\section{Results and Discussion}

The height and base diameter of the seedlings grew in a cubic function as the length of the container increased (Figure 1).

The seedlings with greatest height $(264.8 \mathrm{~cm})$ and base diameter $(68.5 \mathrm{~mm})$ were those with a $125 \mathrm{~cm}$ root system; those with the smallest height $(132.5 \mathrm{~cm})$ and base diameter $(50.1 \mathrm{~mm}$ ) had a $25 \mathrm{~cm}$ root system (Figure 1).

The planting of the seedlings with greater height (tall seedling) provided an anticipated production by having a shorter juvenile period (Santos et al., 2017), and greater field resistance since the root system explored a wider soil volume (Beyer et al., 2016), resulting in higher yields (Figure 2).

The total titratable acidity, total soluble solids, ratio, mean fruit mass of harvests 1 and 2 , and the number of fruits per plant in harvest 2 were not significantly influenced $(p>0.05)$ by the length of the root system (Table 1).

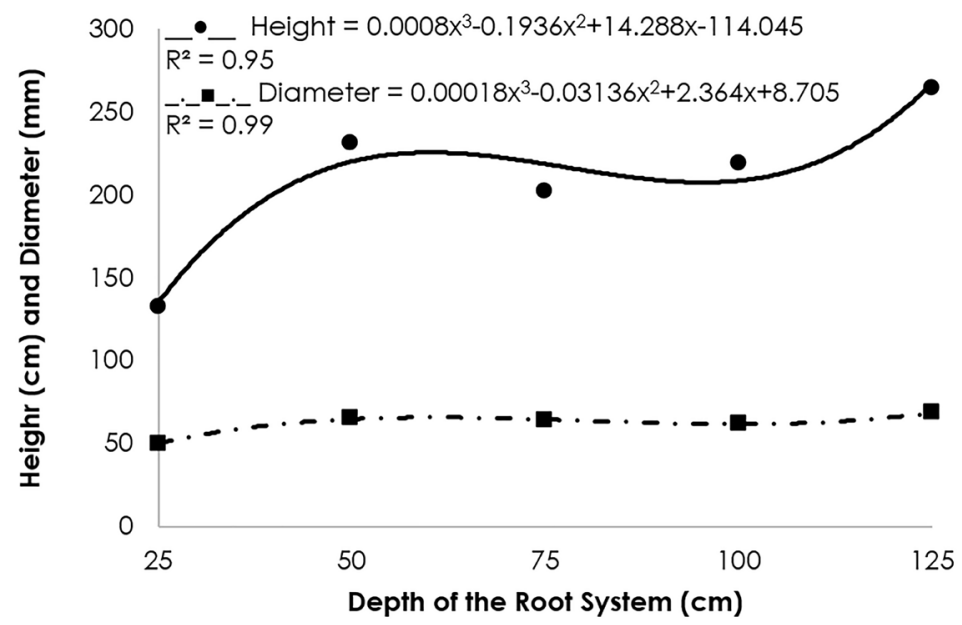

Figure 1. Height and diameter of passion fruit seedlings at 120 days after emergence as a function of the length of the root system. Seridó Ecological Site, Rio Branco, AC, 2015.

Table 1. Total titratable acidity (TTA), total soluble solids (TSS), ratio (SST/ATT), mean fruit mass of harvests 1 (MFM S1) and 2 (MFM S2), and number of fruits per plant in harvests 1 (NFP S1) and 2 (NFP S2) of passion fruits with long root system. Seridó Ecological Site, Rio Branco, AC, 2016 and 2017.

\begin{tabular}{cccccccc}
\hline \multirow{2}{*}{ Treatment } & TTA & TSS & Rations & MFM S ${ }^{n s}$ & MFM S $_{2}{ }^{n s}$ & NFP S $_{1}^{*}$ & NFP S $_{2}{ }^{n s}$ \\
\hline 25 & 7.9 & 16.4 & 2.2 & 112.5 & 110.0 & 2 & 60 \\
50 & 7.7 & 16.2 & 2.3 & 110.9 & 98.7 & 9 & 49 \\
75 & 7.6 & 15.6 & 2.2 & 104.3 & 102.7 & 7 & 48 \\
100 & 7.7 & 16.2 & 2.3 & 105.5 & 103.8 & 16 & 73 \\
125 & 7.9 & 15.9 & 2.2 & 100.9 & 104.9 & 10 & 73 \\
\hline Mean & 7.8 & 16.1 & 2.2 & 106.8 & 103.9 & 8.8 & 60.6 \\
C.V. $(\%)$ & 11.5 & 3.8 & 13.8 & 2.7 & 7.5 & 58.9 & 23.3 \\
\hline * Significant $(p<0.05)$ between treatments by the F test at 5\% probability. & & & &
\end{tabular}

$n s=$ No significant effect $(p>0.05)$ between treatments by the $F$ test at $5 \%$ probability.

The acidity percentage was higher $(p<0.05)$ than that found by Botelho et al. (2016), Santos et al. (2013), and Hafle et al. (2009), which rated $3.25 \%, 3.82 \%$, and $5.02 \%$, respectively. These differences may be related to the cultivar and factors of edaphoclimatic origin, which influence plant nutrition, photosynthesis rates, and the ripening process of the fruits. In the processing industries, it is important that the fruits present high contents of titratable acidity, allowing nutritional and organoleptic improvements and food safety as a consequence of the decrease in the addition of artificial acidifiers to the juice (Raimundo et al., 2009).

The contents of soluble solids (Table 1) are above $(p<0.05)$ those found by Krause et al. (2012), Dias et al. (2017), Santos et al. (2017), and Botelho et al. (2016), which were $13.80 \%, 13.65 \%, 12.83 \%$, and $12.65 \%$, respectively.

In the organic cultivations, the fruits presented higher contents of soluble solids when compared to fruits from conventional cultivation (Oliveira et al., 2017). The higher contents of soluble solids in the composition of the fruits increased the industry yield since the higher is the concentration of TSS, the lower will be the number of fruits used to obtain the pulp in the preparation of the concentrated juice, being necessary $11 \mathrm{~kg}$ of fruits with TSS between 11 and $12^{\circ}$ Brix to obtain $1 \mathrm{~kg}$ of concentrated juice at $50^{\circ}$ Brix (Negreiros et al., 2008). 
The ratio value (Table 1) was lower $(p<0.05)$ than the 3.95 and 4.01 values found by Botelho et al. (2016) and Negreiros et al. (2008), respectively. The low TSS/ TTA relation occurred as a consequence of the high acidity content, which, according to Aguiar et al. (2017) and Vianna-Silva et al. (2008), may undergo variation as a function of the temperature, water demand, and cultivation practices, directly reflecting on the ratio value. However, mean ratio values obtained by Uchôa et al. (2018) in organic passion fruit were similar $(p>0.05)$ to those found in this work.

The mean fruit mass of harvests 1 and 2 was not influenced by the length of the root system (Table 1), and the mean values are in accordance with the masses obtained for the organic cultivation in the region (Rezende et al., 2017; Uchôa et al., 2018). According to Dias et al. (2017), for direct selling, the external appearance and the size of the fruit are the most evaluated attributes by the consumers.
The mean yield of fruits per plant in harvest 1 followed a linear trend $\left(y=0.0844 x+2.145 R^{2}=0.4694\right)$ with an addition of 2.11 fruits plant ${ }^{-1}$ at every $25 \mathrm{~cm}$ of length in the root system (Table 1). This yield increase may have occurred due to the effectivity of the root system in the exploration of greater soil volumes for the absorption of water and nutrients. Therefore, the higher availability of water for the plants with long root system may have provided better conditions for the photosynthetic metabolism, resulting in higher fructification rates.

The harvest time significantly affected the TTA, TSS, and ratio values (Table 2). The total titratable acidity was higher at the beginning of the dry season (May) and lower in the rainy season (Table 2). These results corroborate those found by Vianna-Silva et al. (2008), which may be related to the higher biomass of the fruits, lower total rainfall, and milder temperatures in the drought period.

Table 2. Total titratable acidity (TTA), total soluble solids (TSS) and ratio (TSS/TTA) of passion fruits originated from plants with long root system, in two seasons. Seridó Ecological Site, Rio Branco, AC, 2016.

\begin{tabular}{cccc}
\hline Season & TTA $(\%)$ & TSS (\%) & Ratio \\
\hline May $\left(\mathrm{EP}_{1}\right)$ & $4.93 \mathrm{a}$ & $15.72 \mathrm{a}$ & $3.21 \mathrm{~b}$ \\
Noveber $\left(\mathrm{EP}_{2}\right)$ & $4.29 \mathrm{~b}$ & $16.07 \mathrm{a}$ & $3.81 \mathrm{a}$ \\
\hline $\mathrm{CV}(\%)$ & 12.05 & 4.09 & 14.54 \\
\hline
\end{tabular}

Means followed by distinct letters in the column are statistically different $(\mathrm{p}<0.05)$ by Tukey's test.

The lowest ratio of the pulp was observed in the final period of the rainy season (May), and the highest ratio was observed at the beginning of the rainy season (Table 2). Although the TSS in the seasons did not present differences, the TTA was superior in the drought season, becoming a decisive factor to reduce the ratio value (Negreiros et al., 2008).

The contents of total soluble solids did not present any significant difference ( $p>0.05$ ) in the two evaluated seasons (Table 2). The concentration of TSS in the fruits depends on the development factors of the plants under high temperatures and light intensity since, according to Larcher (2004), in tropical regions, there is greater production of photoassimilates as a consequence of the higher photosynthetic rates.

The cultivation of passion fruit using tall seedlings with long root system influenced the yield of harvests 1 and 2 and the total yield (Figure 2).

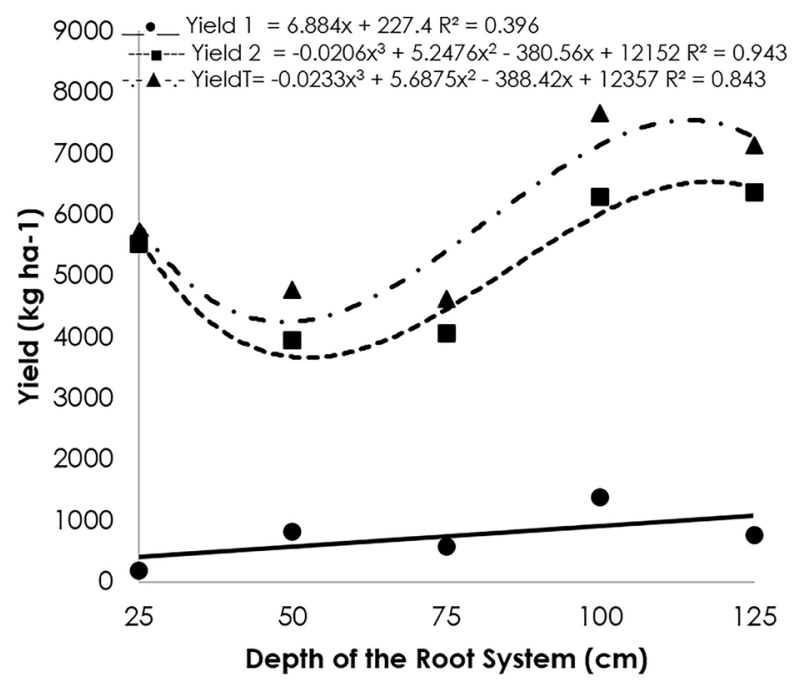

Figure 2. Yield of harvests 1 and 2 and total yield of passion fruit as a function of different lengths of the root system. Seridó Ecological Site, Rio Branco, AC, 2016 a 2017. 
In harvest 1, there was an addition of $6.88 \mathrm{~kg} \mathrm{ha}^{-1}$ for every centimeter increased in the root system. As for harvest 2, the number of fruits was 61 fruits plant ${ }^{-1}$, similarly to the values obtained by Araújo et al. (2009) (Figure 2).

The plants originated from seedlings with root systems between $100 \mathrm{~cm}$ and $125 \mathrm{~cm}$ presented higher yields in harvests 1 and 2, as well as total yield (Figure 2). This may be related to the greater height and base diameter of these plants when taken to the field (Figure 1), since they possess a shorter juvenile period (Santos et al., 2017) and higher capacity of water absorption due to the greater soil volume explored by the roots (Beyer et al., 2016; Mattar et al., 2018; Souza et al., 2008).

The highest total estimated yield was $7,472 \mathrm{~kg} \mathrm{ha}^{-1}$ in the cultivation of plants with an estimated root system of $114 \mathrm{~cm}$, ranking below the mean of the state, $8,270 \mathrm{~kg}$ ha $^{-1}$ (IBGE, 2016), and the yields verified by Araújo Neto et al. (2009) and Araújo Neto et al. (2014), which were $10,200 \mathrm{~kg} \mathrm{ha}^{-1}$ and $21,677.2 \mathrm{~kg} \mathrm{ha}^{-1}$ respectively.

In spite of a mathematical reduction in the yield for the plants with $50 \mathrm{~cm}$ root system, there was no statistical difference in the yield for the plants with 25,50 , and $75 \mathrm{~cm}$ (Figure 2).

This low yield may be related to the prolonged drought period (from May to September), whose rainfall was $218.5 \mathrm{~mm}$ (INMET, 2017) and did not attend to the water demand of the development stages of flowering, formation, and maturation of fruits (betwen 150 and 210 DAT), which demand $954.98 \mathrm{~mm}$ (Silva \& Klar, 2002), as a consequence of the higher accumulation of leaf area and fruit production.

The tolerance of the plant in possessing greater stability and efficiency in the use of solar energy under low water availability depends on the genotype (Gomes et al., 2012), which intimately depends on the growth of the root system, with the available volume of soil being limiting for the expansivity of the roots (Zaccheo et al., 2013; Silva et al., 2015; Santos et al. 2017;).

Plants with a long root system are more able to absorb water in deepest soil layers and, consequently, the greater water availability provided better conditions for the photosynthetic metabolism (Taiz \& Zeiger, 2013), resulting in higher fructification rates (Figure 2).

The functional balance between the absorption of water by the roots and the performing of photosynthesis by the shoot part contributes to the balanced growth of the ratio between the shoot part and the root system of the plants. The roots shall grow so far as the production of photoassimilates by the shoot part does not become limiting. Likewise, the development of the shoot part shall occur so far as the water absorption by the roots becomes limiting to growth. When there is a lower translocation of water for the shoot part before the photosynthetic activity is affected, a decrease in leaf expansion occurs, reducing the consumption of carbon and energy. With that, greater proportions of plant assimilates can be allocated to the roots (Taiz \& Zeiger, 2013), and these, according to Beyer et al. (2016) and Larcher (2004), tend to grow and explore greater volumes of soil in search of water and nutrients when there is low water availability.

The use of tall seedlings with a long root system may have provided greater tolerance to climatic adversities and the maintenance of fruit production even in drought times (Figure 2). This maintenance in production in periods of low water availability (from May to September) proves the efficacy of the use of seedlings with a long root system. Furthermore, the "tall seedling" with greater formation time in the plant nursery can result in greater yield to the detriment of its greater resistance to abiotic factors, since these possess a developed root system and greater biomass accumulation (Santos et al., 2017).

\section{Conclusions}

The quality of the fruits expressed by the content of soluble solids (TSS), total titratable acidity (TTA), and ratio (SST/ATT), as well as the mean fruit mass, were not altered by the length of the root system.

The chemical composition of the soil is influenced by the harvest season. Fruits harvested in may present a juice with higher acidity content.

The cultivation of passion fruit in an organic system, using plants with an estimated root length of 114 $\mathrm{cm}$ provides higher fruit yield $\left(7,472 \mathrm{~kg} \mathrm{ha}^{-1}\right)$ in 22 months of cultivation.

\section{Acknowledgments}

The National Council for Scientific and Technological Development (CNPq), for the concession of scholarships for the authors.

The present work was performed with the support of the Coordination for the Improvement of Higher Education Personnel - Brazil (CAPES - Financing code $001)$.

\section{References}

Aguiar, A.V.M., Cavalcante, L.F., Silva, R.M., Dantas, T.A.G., Santos, E.C. 2017. Effect of biofertilization on yellow passion fruit production and fruit quality. Revista Caatinga 30: 136-148. 
Alvares, C.A., Stape, J.L., Sentelhas, P.C., Gonçalves, J.L.M., Sparovek, G. 2014. Köppen's climate classification map for Brazil. Meteorologische Zeitschrift 22: 71 1-728.

AOAC. ASSOCIATION OF OFFICIAL ANALYTICAL CHEMISTS. 2012. Official methods of analysis. 19.ed. Arlington.

Araújo Neto, S.E., Campos, P.A., Tavella, L.B., Solino, A.J.S., Silva, I.F. 2014. Organic polyculture of passion fruit, pineapple, corn and cassava: the influence of green manure and distance between espaliers. Ciência e Agrotecnologia 38: 247-255.

Araújo Neto, S.E., Ferreira, R.L.F., Pontes, F.S.T., Negreiros, J.R.S. 2008. Rentabilidade econômica do maracujazeiroamarelo plantado em covas e em plantio direto sob manejo orgânico. Revista Brasileira de Fruticultura 30: 940945.

Araújo Neto, S.E., Souza, S.R., Saldanha, C.S., Fontinele, Y.R., Negreiros, J.R.S., Mendes, R., Azevedo, J.M.A, Oliveira, E.B.L. 2009. Produtividade e vigor do maracujazeiroamarelo plantado em covas e plantio direto sob manejo orgânico. Ciência Rural 39: 678-683.

Beyer, M., Koeniger, P., Gaj, M., Hamutoko, J.T., Wanke, H., Himmelsbach, T. 2016. A deuterium-based labeling technique for the investigation of rooting depths, water uptake dynamics and unsaturated zone water transport in semiarid environments. Journal of Hydrology 533: 627643.

Botelho, S.C.C., Miguel-Wruck, D.S., Roncatto, G., Oliveira, S.S., Botelho, F.M., Wobeto, C. 2016. Qualidade pós-colheita de maracujá-amarelo em função de portaenxertos e ambientes de cultivo. Comunicata Scientiae 7: 504-512.

Dias, D.G., Pegoraro, R.F., Maia, V. M., Medeiros, A.C. 2017. Production and postharvest quality of irrigated passion fruit after N-K fertilization. Revista Brasileira de Fruticultura 39: (e-553).

Gomes, M.T.G., Luz, A.C., Santos, M.R., Batitucci, M.C.P., Silva, D.M., Falqueto, A.R. 2012. Drought tolerance of passion fruit plants assessed by the OJIP chlorophyll a fluorescence transiente. Scientia Horticulturae 142: 49-56.

Hafle, O.M., Ramos, J.D., Lima, L.C.O., Ferreira, E.A., Melo, P.C. 2009. Produtividade e qualidade de frutos do maracujazeiro-amarelo submetido à poda de ramos produtivos. Revista Brasileira de Fruticultura 31: 763-770.

IBGE. Instituto Brasileiro de Geografia e Estatística. 2016. http://www.sidra.ibge. gov.br/bda/tabela/listabl. asp? $c=1613 \& z=p \& O=28<$ Acess on 06 Jan. 2018>

INMET. Instituto Nacional de Meteorologia. 2017. http:// www.inmet.gov.br/portal/ index. php?r=bdmep/ bdmep<Acess on 23 Dec. 2017>

Krause, W., Neves, L.G., Viana, A.P., Araújo, C.A.T., Faleiro, F.G. 2012. Produtividade e qualidade de frutos de cultivares de maracujazeiro-amarelo com ou sem polinização artificial. Pesquisa Agropecuária Brasileira 47: 1737-1742.
Larcher, W. 2004. Ecofisiologia vegetal. Trad. Prado, C.H.B.A. RiMa, São Carlos, Brazil. 531 p.

Mattar, G.S., Moraes, C.C., Meletti, L.M.M., Purquerio, L.F.V. 2018. Accumulation and exportation of nutrientes by yellow Passion fruit cV. IAC 275. Revista Brasileira de Fruticultura 40: (e-178).

Meletti, L.M.M. 2011 . Avanços na cultura do maracujá no Brasil. Revista Brasileira de Fruticultura 33: 83-91.

Negreiros, J.R.S., Araújo Neto, S.E., Álvares, V.S., Lima, V.A., Oliveira, T.K. 2008. Caracterização de frutos de progênies de meios-irmãos de maracujazeiro amarelo em Rio Branco - Acre. Revista Brasileira de Fruticultura 30: 431-437.

Oliveira, A.B., Lopes, M.M.A., Moura, C.F.H., Oliveira, L.S., Souza, K.O., Gomes Filho, E., Urbano, L., Miranda, M.R.A. 2017. Effects of organic vs. conventional farming systems on quality and antioxidant metabolism of passion fruit during maturation. Scientia Horticulturae 222: 84-89.

Raimundo, K., Magri, R.S., Simionato, E.M.R.S., Sampaio, A.C. 2009. Avaliação física e química da polpa de maracujá congelada comercializada na região de Bauru. Revista Brasileira de Fruticultura 31: 539-543.

Rezende, M.I.F.L., Araújo Neto, S.E., Lustosa, C., Hafle, O.M., Pinto, G.P. 2017. Grafting for the recovery of yellow passion fruit stem in organic system. Revista Brasileira de Fruticultura 39: (e-745).

Santos, J.L.V., Resende, E.D., Martins, D.R., Gravina, G.A., Cenci, S.A., Maldonado, J.F.M. 2013. Determinação do ponto de colheita de diferentes cultivares de maracujá. Revista Brasileira de Engenharia Agrícola e Ambiental 17: 750-755.

Santos, V.A., Ramos, J.D., Laredo, R.R., Silva, F.O.R., Chagas, E.A., Pasqual, M. 2017. Produção e qualidade de frutos de maracujazeiro-amarelo provenientes do cultivo com mudas em diferentes idades. Revista de Ciências Agroveterinárias 16: 33-40.

Silva, A.A.G., Klar, A.E. 2002. Demanda hídrica do maracujazeiro amarelo (Passiflora edulis Sims f. flavicarpa Deg.). Irriga 7: 185-190.

Silva, C.R.A., Ribeiro, A., Oliveira, A.S., Klippel, V.H., Barbosa, R.L.P. 2015. Desenvolvimento biométrico de mudas de eucalipto sob diferentes lâminas de irrigação na fase de crescimento. Revista Pesquisa Florestal Brasileira 35: 381-390.

Silva, R.S., Araújo Neto, S.E., Silva, N.M., Silva, D.F., Souza, L.G.S, Uchôa, T.L. 2018. Produção de mudas orgânicas de maracujazeiro-amarelo com sistema radicular longo. Agropecuária Científica no Semiárido 14: 7-12.

Souza, P.U., Lima, L.K.S., Soares, T.L., Jesus, O.N., Coelho Filho, M.A., Girardi, E.A. 2018. Biometric, physiological and anatomical responses of Passiflora spp. to controlled water deficit. Scientia Horticulturae 229: 77-90.

Taiz, L., Zeiger, E. 2013. Fisiologia vegetal. Artmed, Porto Alegre, Brazil. 918 p. 
Uchôa, T.L., Araújo Neto, S.E., Selhorst, P.O., Rodrigues, M.J.S., Galvão, R.O. 2018. Yellow Passion fruit performance in organic crop under mulch. Revista Brasileira de Fruticultura 40: (e-212).

Vianna-Silva, T., Resende, E.D., Viana, A.P., Pereira, S.M.F., Carlos, L.A., Vitorazi, L. 2008. Qualidade do suco de maracujá-amarelo em diferentes épocas de colheita. Ciência de Tecnologia de Alimentos 28: 545-550.

Zaccheo, P.V.C., Aguiar, R.S., Stenzel, N.M.C., Neves, C.S.V.J. 2013. Tamanho de recipientes e tempo de formação de mudas no desenvolvimento e produção de maracujazeiro-amarelo. Revista Brasileira de Fruticultura 35: 603-607.

Conflict of Interest Statement: The authors declare that the research was conducted in the absence of any commercial or financial relationships that could be construed as a potential conflict of interest.

All the contents of this journal, except where otherwise noted, is licensed under a Creative Commons Attribution License attribuition-type BY. 